\title{
Multidrug-resistant Staphylococcus aureus (MDRSA) properties and their adherence ability on stainless steel surfaces at different temperature and time
}

\author{
${ }^{1}$ Nur-Syifa', J., ${ }^{1 *}$ Nor-Khaizura, M.A.R., ${ }^{2}$ Mahyudin, N.A., ${ }^{1}$ Shafiqa-Atikah, M.K. and \\ ${ }^{1}$ Ummul-Izzatul, Y. \\ ${ }^{1}$ Department of Food Science, Faculty of Food Science and Technology, Universiti Putra Malaysia, 43400 \\ UPM Serdang Selangor, Malaysia. \\ ${ }^{2}$ Department of Food Service and Management, Faculty of Food Science and Technology, Universiti Putra \\ Malaysia, 43400 UPM Serdang Selangor, Malaysia.
}

\section{Article history: \\ Received: 24 October 2019 \\ Received in revised form: 4 April 2020 \\ Accepted: 27 April 2020 \\ Available Online: 16 May 2020}

\section{Keywords:}

Staphylococcus aureus,

Food contact surfaces,

Multidrug-resistant,

Stainless steel,

Cell adherence

DOI:

https://doi.org/10.26656/fr.2017.4(S2).S07

\begin{abstract}
Staphylococcus aureus is a pathogenic bacterium that capable to adhere on the processing surfaces that could cause a cross-contamination of foods. In Malaysia, S. aureus has been reported from foods and food-handlers hand at food service environment but the multidrug -resistant $S$. aureus (MDRSA) and their adherence on stainless steel were limited. This study was intended 1) to isolate $S$. aureus from food contact surfaces and characterize the isolates for MDRSA properties, and 2) to determine the adherence ability of the MDRSA strains. A total of thirty-eight $S$. aureus isolated from food premises in Sri Serdang were tested for the antibiotic resistance and it was carried out using five classes of antibiotics; Penicillin (I), Cephalosporins (II), Amino-glycosides (III), Quinolones Fluoroquinolone (IV), and Sulphonamide (V) by the standard procedures of Kirby-Bauer disc diffusion method. The adherence assay was performed on stainless steel disc at $25^{\circ} \mathrm{C}$ and $37^{\circ} \mathrm{C}$ on 24, 48 and $72 \mathrm{hrs}$ incubation. As a result, twenty-three S. aureus were found as multidrugresistant towards the antibiotics. All the MDRSA can adhere on stainless steel with a minimum $4.00 \log \mathrm{CFU} / \mathrm{mL}$. The adherence of MDRSA on stainless steel during $72 \mathrm{hrs}$ were ranging from 4.11 to $6.55 \log \mathrm{CFU} / \mathrm{mL}$ and 4.25 to $6.86 \log \mathrm{CFU} / \mathrm{mL}$ at $25^{\circ} \mathrm{C}$ and $37^{\circ} \mathrm{C}$, respectively. The highest adherence was found on $48 \mathrm{hrs}$ at both temperatures. The MDRSA strains revealed high capacity to adhere on stainless steel at $37^{\circ} \mathrm{C}$. As a conclusion, the MDRSA strains shows the strong adherence ability at their optimum growth temperature.
\end{abstract}

\section{Introduction}

Staphylococcus aureus known as a main human pathogen that has cause widespread infection worldwide. It is the most common enterotoxigenic staphylococcal species causing foodborne disease (Abdollah et al., 2014). Amongst the reported foodborne illnesses, $S$. aureus got the highest prevalence rate of resistant $S$. aureus infections reported in Asia (Sit et al., 2017). Recently, a massive $S$. aureus food poisoning outbreak occurred, involving primary school students in Bangi, Selangor, Malaysia, in 2017 (Baharudin and Mohd Ishak, 2017). As a pathogenic bacterium that able to have antimicrobial resistance properties and capable to adhere on the food processing surfaces, $S$. aureus could cause the food contamination and health threat once it conveys to human (Malheiros et al., 2010; Ciccio et al., 2015).
Several studies have found the antibiotic resistant $S$. aureus on work surfaces, human and in food processing environment. $S$. aureus can adapt near developed protective mechanisms to reduce susceptibility against antibiotics (Hogberg et al., 2010). The antibiotic resistant genes are transferred among bacteria by carried on mobile genetic elements and spread via gene exchange processes. The indiscriminate usage of antibiotics offered the condition to mobilise gene resistant into pathogenic bacteria (Wise, 2002; Wright, 2007). Thus, resistance to each antibiotic used in medical work has now been reported (Payne et al., 2007). Additionally, $S$. aureus is a pathogen with combination of toxin-mediated virulence, and has gotten frighteningly resistant to numerous antibiotics (Beceiro et al., 2013; Kadariya et al., 2019). A multidrug-resistant S. aureus (MDRSA) are a growing global danger, consequently challenging the treatment of $S$. aureus infections. 
The lack of hygienic practices amongst food handlers particularly during preparation can contaminate food-contact surfaces such as cutting boards and these are the major factors causing $S$. aureus contamination in food products (DeVita et al., 2007). Several studies have found the adherence of $S$. aureus planktonic cells on labour surfaces including polypropylene, glass and stainless steel (Herrera et al., 2006; DeVita et al., 2007). However, the changes in environmental properties may lead to persistence of staphylococcal on food contact environment. More recent studies have suggested $S$. aureus to have a high capability of adhering and forming biofilm on stainless steel and polypropylene surfaces (Jeronimo et al., 2012; Meira et al., 2012; Souza et al., 2014).

In Malaysia, the adherence of $S$. aureus has been reported in dairy products (Sasidharan et al., 2011), foods, as well as in the nostrils (Noor-Azira et al., 2012) and hands of food-handlers on foodservice premises (Tan et al., 2014). However, the findings on the survival of multidrug-resistant $S$. aureus (MDRSA) on food contact surfaces at different temperature and time are limited. Therefore, the objectives of this work are 1) to isolate $S$. aureus from food contact surfaces and characterize the isolates for MDRSA properties, and 2) to determine the adherence ability of the MDRSA strains on stainless steel surfaces at different temperature and time.

\section{Materials and methods}

\subsection{Sample collection}

A total of twenty-four isolates of $S$. aureus were obtained from a stock culture in the Food Safety and Microbiology Laboratory, Universiti Putra Malaysia, Serdang, Selangor (Shakira, 2016). Another 45 samples were collected from food contact surface at the food premises of Universiti Putra Malaysia (UPM), Serdang, Selangor. The samples were isolated from the surface of cutting board, tray, plate and wok by standard swabbing method. Sampling was done by swabbing these surfaces horizontally, vertically and diagonally of $10 \mathrm{~cm}$ x $10 \mathrm{~cm}$.

\subsection{Isolation of Staphylococcus aureus}

The collected samples $(n=45)$ were enriched in Nutrient Broth (NB) (Oxoid, Basingstoke, UK) overnight. An aliquot of $0.1 \mathrm{~mL}$ was spread on a Nutrient Agar (NA) (Oxoid, Basingstoke, UK) plate and incubated at $37^{\circ} \mathrm{C}$ for 18 to $24 \mathrm{hrs}$. The grown colonies were isolated using selective agar; Mannitol Salt Agar (MSA), and Baird Parker Agar (BPA) supplemented with egg yolk tellurite (Oxoid, Basingstoke, UK). The growth colonies on MSA and BPA were observed and the suspected colonies were identified using biochemical tests.

\subsection{Identification of Staphylococcus aureus using biochemical test}

The isolates were then confirmed by Gram-staining, a catalase test, and a coagulase test. A single colony of $S$. aureus revived from NA plates was identified. Standard method for Gram-staining (Lucia et al., 2017), catalase (Public Health England, 2014) and coagulase test (Thirunavukkarasu and Rathish, 2014) were performed accordingly. The reaction of the isolates upon these tests were shown in Table 1, indicate that the isolates tested positive for $S$. aureus.

\subsection{Determination of Multidrug-resistant Staphylococcus aureus (MDRSA)}

All thirty-eight isolates (stock cultures, $\mathrm{n}=24$; new isolates, $\mathrm{n}=14$ ) that have been identified as $S$. aureus (numbered as SA001-SA038) were tested for their resistance against the antibiotics. Eleven antibiotics; penicillin $\mathrm{G}(10 \mu \mathrm{g})$, amoxicillin $(10 \mu \mathrm{g})$, ceftriaxone $(5$ $\mu \mathrm{g})$, ceftazidime $(30 \mu \mathrm{g})$, cephalothin $(30 \mu \mathrm{g})$, cefotaxime $(30 \mu \mathrm{g})$, gentamicin $(10 \mu \mathrm{g})$, streptomycin $(25 \mu \mathrm{g})$, nalidixic acid $(30 \mu \mathrm{g})$, ciprofloxacin $(5 \mu \mathrm{g})$, sulphafurazole $(300 \mu \mathrm{g})$ (Oxoid, Basingstoke, UK) have been used. It was chosen according to their mechanism which are; $\beta$-Lactams and non $\beta$-Lactams (Table 2). Antibiotic tested comes from five antibiotic classes; Penicillin (I), Cephalosporins (II), Amino-glycosides (III), Quinolones Fluoroquinolone (IV) and Sulphonamide (V) which to indicate the presence of multidrug-resistant $S$. aureus. The test was carried by using the standard procedures of the Kirby-Bauer disc diffusion method. Inoculum was obtained from overnight fresh cultures on Tryptic Soy Agar (TSA) (Oxoid, Basingstoke, UK) adjusted to approximately $\log 10^{8}$ $\mathrm{CFU} / \mathrm{mL}$, turbidity equivalent to a 0.5 McFarland standard (Kroning et al., 2016), and spread on Mueller

Table 1. Biochemical test results of $S$. aureus

\begin{tabular}{ll}
\hline \multicolumn{1}{c}{ Parameters } & \multicolumn{1}{c}{ Characteristic of S. aureus } \\
\hline $\begin{array}{c}\text { Selective media } \\
\text { Baird-parker agar }\end{array}$ & Black and shiny with narrow white margins and surrounded by clear zone \\
Mannitol salt agar & Yellow colonies with yellow zones in the media \\
Gram-staining & Positive cocci in clusters \\
Catalase & Appearance of gas bubbles after emulsify with 3\% hydrogen peroxide \\
Coagulase & Clumping cocci within 5-10 seconds resulted with rabbit plasma \\
\hline
\end{tabular}


Table 2. The antibiotics used to determine the resistance of $S$. aureus isolated from food contact surfaces.

\begin{tabular}{ccc}
\hline Antibiotic agent & Group of antibiotics & Antibiotic \\
\hline \multirow{3}{*}{$\beta$-Lactams } & Penicillin (I) & Penicillin G (P) \\
\cline { 2 - 3 } & & Amoxicillin (AMC) \\
\cline { 2 - 3 } & Cephalosporin (II) & Ceftriaxone (CRO) \\
& & Ceftazidime (CAZ) \\
& & Cephalothin (KF) \\
Non $\beta$-Lactams & Aminoglycosides (III) & Cefotaxime (CTX) \\
\cline { 2 - 3 } & & Suinolonicin (CN) \\
& \multirow{2}{*}{ Quino Fluoroquinolone (IV) } & Nalidixic acid (NA) \\
\cline { 2 - 3 } & & Ciprofloxacin (CIP) \\
\cline { 2 - 3 } & Sulfonamides (V) & Sulfisoxazole (SF) \\
\hline
\end{tabular}

Hinton Agar (MHA) surfaces. The antibiotic discs were then placed onto the inoculated MHA and incubated overnight at $37^{\circ} \mathrm{C}$. The results were interpreted according to the standards of inhibition zone diameters for Staphylococcus spp. (CLSI, 2015). Staphylococcus aureus ATCC 13565 was used as the positive control for the tests.

\subsection{Molecular identification of MDRSA}

A total of fourteen presumptive $S$. aureus of new isolates were then confirmed by the molecular identification. Genotypic by DNA extracted from presumptive $S$. aureus isolates and the PCR were carried out by 16s ribosomal RNA gene sequencing method. These were confirmed by Bacterial DNA Barcoding, full -length of 16s rRNA ( 1400 bp), 1st BASE MBS. This method is for identifying and confirmed all the staphylococcal isolates as $S$. aureus. In brief, for rapid DNA extraction, one to five colonies of each freshly subcultured strain were suspended in $50 \mu \mathrm{L}$ sterile peptone water (SPW) and heated at $99^{\circ} \mathrm{C}$ for 10 mins. After centrifugation at $30,000 \times g$ for $1 \mathrm{~min}$, the supernatant was used as a DNA template and stored at $20^{\circ} \mathrm{C}$ until PCR was performed.

\subsection{Adherence of MDRSA at different temperature and time on stainless steel surface}

\subsubsection{MDRSA strains preparation}

All twenty-three MDRSA strains were grown overnight (18 to $24 \mathrm{hrs})$ at $37^{\circ} \mathrm{C}$ with shaking $150 \times g$ (gravity) in Tryptic Soy Broth (TSB) (Merck, Germany). The cells were harvested by centrifugation at $5000 \times g$ for $3.5 \mathrm{mins}$ and washed three times in phosphate buffered saline (PBS; 0.1M, pH 7.2). For the strains suspension, cell pellets were re-suspended in PBS and adjusted using a spectrophotometer to an A600 of approximately 0.5 , corresponding to $\log 10^{8} \mathrm{CFU} / \mathrm{mL}$ (Arellano, 2010; Cabeça et al., 2012).

\subsubsection{Test surfaces and experimental conditions}

AISI-304 stainless steel disc $(6 \times 6 \times 1 \mathrm{~mm})$ were used as the test surfaces. The discs were individually cleaned, sanitized and sterilized according to the procedure described by Marques et al. (2007). The adherence of MDRSA strains on the stainless steel surfaces inoculated into Tryptic Soy Broth (TSB), were assessed at two different temperature, $25^{\circ} \mathrm{C}$ and $37^{\circ} \mathrm{C}$ for 24, 48 and $72 \mathrm{hrs}$ incubation time.

\subsubsection{Cell adherence and the quantification}

A suspension of $50 \mu \mathrm{L}\left(10^{8} \mathrm{CFU} / \mathrm{mL}\right)$ was mixed with $100 \mu \mathrm{L}$ of Brain Heart Broth (Merck, Germany). The mixture was pipetted to the centre of the stainless steel disc and incubated at $25^{\circ} \mathrm{C}$ and $37^{\circ} \mathrm{C}$. After 24,48 and $72 \mathrm{hrs}$ of incubation, discs were withdrawn and immersed for $15 \mathrm{~s}$ in sterile peptone water (SPW, 0.1 $\mathrm{g} / 100 \mathrm{~mL}$ ) to release the non-adhered cells. The surface of the stainless steel disc was swabbed using a sterile moistened cotton swab for collecting the cell adherence. The cotton swabs were then re-suspended in $9 \mathrm{~mL}$ of sterile peptone water (SPW) by vigorously vortexing for $30 \mathrm{~s}$. The peptone water was adjusted to a serially diluted $\left(10^{-1}\right.$ to $\left.10^{-6}\right)$ in SPW, and $100 \mu \mathrm{L}$ was spread plated onto a sterile Plate Count Agar (PCA). The plates were incubated at $25^{\circ} \mathrm{C}$ and $37^{\circ} \mathrm{C}$ for $24-48 \mathrm{hrs}$ and the number of viable cells was counted. The results were expressed in $\log \mathrm{CFU} / \mathrm{mL}$ (Rode et al., 2007)

\subsection{Statistical analysis}

The experimental results were statistically analysed using the Microsoft Excel 2013 and Minitab 16 (State College, Pennsylvania) software packages. All experiments were performed in triplicate and the results expressed as an average. The data for cell adherence was normalized and expressed as $\log \mathrm{CFU} / \mathrm{mL}$. A probability value $(\mathrm{p}<0.05)$ was accepted to indicate a significant difference. 


\section{Results and discussion}

\subsection{Identification of Staphylococcus aureus}

Among 45 new samples collected from various food contact surfaces, $14(31.1 \%)$ were found positive as a presumptive $S$. aureus after test on BPA, MSA, gram staining, catalase test and coagulase test (Figure 1). The positive result for the presumptive $S$. aureus were showed as in Table 1 . The stock cultures of $S$. aureus isolates $(\mathrm{n}=24$, which is obtained from food contact surfaces) and the new isolates $(n=14)$ were combined (SA001-SA038) for multidrug resistant test.

\subsection{Determination of MDRSA}

The antibiotics resistant pattern of $38 \mathrm{~S}$. aureus (SA001-SA038) were presented in Table 3. According to the result, $S$. aureus were more resistant to a group of Penicillin (I), Cephalosporin (II) and Quinolones fluoroquinolone (IV). Resistance rates against Penicillin G, Amoxycillin, Ceftazidime, Cephalothin, Ciprofloxacin, and Nalidixic acid were determined as $94.7 \%, 92.1 \%, 34.2 \%, 36.8 \%, 10.5 \%$ and $89.5 \%$ respectively. Penicillin G and Amoxicillin which belong to group Penicillin were determined to be antibiotics with the highest resistant. From the result, twenty-three $(60.5 \%)($ Stock culture $=13$; new isolates $=10)$ were classified as a multidrug-resistant $S$. aureus (MDRSA) (Figure 2) since the isolates were resistant to three or more category of antibiotic group (Magiorakos et al., 2012). The isolates displayed resistant to Penicillin, Cephalosporins, and Quinolones Fluoroquinolone classes of antibiotics. A relatively result was found in the study of Deyno et al. (2017), revealed that the overall rate of MDR was $100 \%$; all of the isolates were found to be resistant to three and more tested antibiotics. Recently, there were $44.2 \%$ and $23.9 \%$ MDRSA isolated from human were reported in Nepal and Northeast Ohio (NEO) (Kadariya et al., 2019). This result support that the study of MDRSA was important since it became high occurrence in worldwide. In addition, the positive MDRSA from new isolates (SA14-SA23) were then tested for their confirmation as $S$. aureus by molecular identification, since the isolates from stock culture (SA01-SA13) were already confirmed as $S$. aureus in previous study.

\subsection{Confirmation of MDRSA by 16 s rRNA sequences}

All MDRSA for new $S$. aureus isolates were confirmed by $16 \mathrm{~s}$ rRNA sequences. A total of ten MDRSA were showed positive as $S$. aureus in gene sequencing. These isolates proved to be $S$. aureus after the genetic detection of $S$. aureus by $16 \mathrm{~s}$ rDNA. The forward and reverse sequencing results are edited and assembled into one full-length sequence. Table 4 showed blast results against NCBI $16 \mathrm{~S}$ ribosomal RNA sequences.

\subsection{Adherence ability of MDRSA at $25^{\circ} \mathrm{C}$ and $37^{\circ} \mathrm{C}$}

The adherence ability of the twenty-three MDRSA strains at $25^{\circ} \mathrm{C}$ and $37^{\circ} \mathrm{C}$ on 24,48 and $72 \mathrm{hrs}$ were tested, and the results were expressed in $\log \mathrm{CFU} / \mathrm{mL}$. All 23 strains showed the capability to adhere to the stainless steel disc with a minimum cell count of $4.00 \mathrm{log}$ $\mathrm{CFU} / \mathrm{mL}$. Figure 3 shows the number of viable cell adhered on stainless steel disc at temperature $25^{\circ} \mathrm{C}$ and $37^{\circ} \mathrm{C}$ during 24,48 and $72 \mathrm{hrs}$ were ranging from 4.11 to $6.55 \log \mathrm{CFU} / \mathrm{mL}$ and 4.25 to $6.86 \log \mathrm{CFU} / \mathrm{mL}$, respectively. At $24 \mathrm{hrs}$ incubation, 5 and 13 strains have high adherence with 6.01 to $6.81 \log \mathrm{CFU} / \mathrm{mL}$ at $25^{\circ} \mathrm{C}$ and $37^{\circ} \mathrm{C}$, respectively while at $48 \mathrm{hrs}, 6$ and 9 strains have high adherence with ranging from 6.05 to $6.86 \mathrm{log}$ $\mathrm{CFU} / \mathrm{mL}$ at $25^{\circ} \mathrm{C}$ and $37^{\circ} \mathrm{C}$, respectively. At $72 \mathrm{hrs}$ incubation, only SA21 and SA05 was good in adhered on stainless steel disc at $25^{\circ} \mathrm{C}$ and $37^{\circ} \mathrm{C}$, with $6.28 \log \mathrm{CFU} /$ $\mathrm{mL}$ and $6.12 \log \mathrm{CFU} / \mathrm{mL}$, respectively. SA01 show poor adherence with the lowest cell growth (4.11 log $\mathrm{CFU} / \mathrm{mL}$ and $4.25 \log \mathrm{CFU} / \mathrm{mL}$ ) for both temperature at $24 \mathrm{hrs}$. These results revealed the MDRSA strains have high capability to adhere on stainless steel surfaces at 48 hrs incubation compared to $24 \mathrm{hrs}$ and $72 \mathrm{hrs}$, as the strains adhered with exceeding $6.00 \log \mathrm{CFU} / \mathrm{mL}$ were mostly found at the incubation of $48 \mathrm{hrs}$. From this result, four trends; Trend I, Trend II, Trend III and Trend IV were found in the adherence of MDRSA strains at $25^{\circ} \mathrm{C}$ and $37^{\circ} \mathrm{C}$ as shown in Table 5. Trend III has the highest strains with $34.8 \%$ and $39.1 \%$ of MDRSA at both temperatures, $25^{\circ} \mathrm{C}$ and $37^{\circ} \mathrm{C}$, respectively. It could be the adhesion of bacterial cell is extreme on $48 \mathrm{hrs}$ than $72 \mathrm{hrs}$, which might be the bacterial cell start to remove from the stainless steel disc.

The result present in this study are similar to those reported by Souza et al. (2014), studied of S. aureus from food processing plants surface, found that a population density of 5.00 to $6.00 \log \mathrm{CFU} / \mathrm{mL}$ for the strains after a 24,48 , and $72 \mathrm{hrs}$ contact with stainless steel surface. As discussed regarding the substrate and the extrinsic characteristic have been reported to interfere on the bacterial adherence (Ista et al., 2010; Jeronimo et al., 2012). It was tested regarding the common temperature used in the preparation and processing of food. According to outcome from Meira $e t$ al. (2012) and Jeronimo et al. (2012), the study revealed a clear two-phase of adherence; 1) increasingly the highest numbers of cell adherence after $48 \mathrm{hrs}$, followed by 2 ) decreasing number of cell adherence at $72 \mathrm{hrs}$. The finding suggests, the adhered cells could present in high numbers but do not continuously increase over time 
Identification of $S$. aureus $(\mathrm{n}=45)$

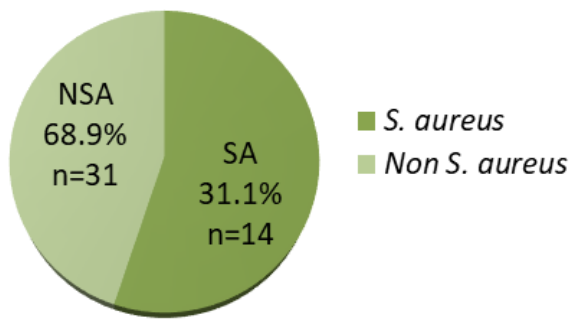

Figure 1. Identification of $S$. aureus isolates collected from food contact surfaces of food premises in Sri Serdang, Selangor.

Table 3. Antibiotics resistant pattern of S. aureus obtained from food contact surfaces in Sri Serdang

\begin{tabular}{|c|c|c|c|c|c|c|c|c|c|c|c|c|}
\hline \multirow{3}{*}{ S. aureus } & \multicolumn{11}{|c|}{ Antibiotics classes $(\mu \mathrm{g})$} & \multirow{3}{*}{$\mathrm{R}$} \\
\hline & \multicolumn{3}{|c|}{ Penicillin (I) } & \multicolumn{3}{|c|}{ Cephalosporin (II) } & \multicolumn{2}{|c|}{$\begin{array}{l}\text { Aminoglycosides } \\
\text { (III) }\end{array}$} & \multicolumn{2}{|c|}{$\begin{array}{c}\text { Quinolones } \\
\text { Fluoroquinolone } \\
\text { (IV) }\end{array}$} & \multirow{2}{*}{$\begin{array}{c}\text { Salphonamides } \\
\text { (V) }\end{array}$} & \\
\hline & $\mathrm{P} 10$ & AML 10 & CRO 5 & CAZ 30 & KF 30 & CTX 30 & CN 10 & $\mathrm{~S} 25$ & CIP 5 & NA 30 & & \\
\hline$\overline{\mathrm{SA} 001}$ & $\mathrm{R}$ & $\mathrm{R}$ & - & - & $\mathrm{R}$ & - & - & - & - & $\mathrm{R}$ & - & 3 \\
\hline SA002 & $\mathrm{R}$ & $\mathrm{R}$ & - & - & - & - & - & - & - & $\mathrm{R}$ & - & 2 \\
\hline SA003 & $\mathrm{R}$ & $\mathrm{R}$ & - & - & $\mathrm{R}$ & - & - & - & - & $\mathrm{R}$ & - & 3 \\
\hline SA004 & $\mathrm{R}$ & $\mathrm{R}$ & - & - & - & - & - & - & - & $\mathrm{R}$ & - & 2 \\
\hline SA005 & $\mathrm{R}$ & $\mathrm{R}$ & - & - & $\mathrm{R}$ & - & - & - & - & $\mathrm{R}$ & - & 3 \\
\hline SA006 & $\mathrm{R}$ & $\mathrm{R}$ & - & $\mathrm{R}$ & - & - & - & - & - & $\mathrm{R}$ & - & 3 \\
\hline SA007 & $\mathrm{R}$ & $\mathrm{R}$ & - & $\mathrm{R}$ & - & - & - & - & - & $\mathrm{R}$ & - & 3 \\
\hline SA008 & $\mathrm{R}$ & $\mathrm{R}$ & - & - & - & - & - & - & $\mathrm{R}$ & $\mathrm{R}$ & - & 2 \\
\hline SA009 & $\mathrm{R}$ & $\mathrm{R}$ & - & - & - & - & - & - & - & $\mathrm{R}$ & - & 2 \\
\hline SA010 & $\mathrm{R}$ & $\mathrm{R}$ & - & $\mathrm{R}$ & - & - & - & - & - & $\mathrm{R}$ & - & 3 \\
\hline SA011 & $\mathrm{R}$ & $\mathrm{R}$ & - & $\mathrm{R}$ & $\mathrm{R}$ & - & - & - & - & $\mathrm{R}$ & - & 3 \\
\hline SA012 & $\mathrm{R}$ & $\mathrm{R}$ & - & - & $\mathrm{R}$ & - & - & - & - & $\mathrm{R}$ & - & 3 \\
\hline SA013 & $\mathrm{R}$ & $\mathrm{R}$ & - & - & - & - & - & - & $\mathrm{R}$ & $\mathrm{R}$ & - & 2 \\
\hline SA014 & $\mathrm{R}$ & $\mathrm{R}$ & - & - & - & - & - & - & $\mathrm{R}$ & $\mathrm{R}$ & - & 2 \\
\hline SA015 & $\mathrm{R}$ & $\mathrm{R}$ & - & - & - & - & - & - & - & $\mathrm{R}$ & - & 2 \\
\hline SA016 & $\mathrm{R}$ & $\mathrm{R}$ & - & - & $\mathrm{R}$ & - & - & - & - & $\mathrm{R}$ & - & 3 \\
\hline SA017 & $\mathrm{R}$ & $\mathrm{R}$ & - & $\mathrm{R}$ & - & - & - & - & - & $\mathrm{R}$ & - & 3 \\
\hline SA018 & $\mathrm{R}$ & $\mathrm{R}$ & - & - & - & - & - & - & - & $\mathrm{R}$ & - & 2 \\
\hline SA019 & $\mathrm{R}$ & $\mathrm{R}$ & - & - & $\mathrm{R}$ & - & - & - & $\mathrm{R}$ & $\mathrm{R}$ & - & 3 \\
\hline SA020 & $\mathrm{R}$ & $\mathrm{R}$ & - & - & - & - & - & - & - & $\mathrm{R}$ & - & 2 \\
\hline SA021 & $\mathrm{R}$ & $\mathrm{R}$ & - & - & - & - & - & - & - & $\mathrm{R}$ & - & 2 \\
\hline SA022 & $\mathrm{R}$ & $\mathrm{R}$ & - & - & - & - & - & - & - & $\mathrm{R}$ & - & 2 \\
\hline SA023 & $\mathrm{R}$ & $\mathrm{R}$ & - & - & $\mathrm{R}$ & - & - & - & - & $\mathrm{R}$ & - & 3 \\
\hline $\mathrm{SA} 024$ & $\mathrm{R}$ & $\mathrm{R}$ & - & - & $\mathrm{R}$ & - & - & - & - & $\mathrm{R}$ & - & 3 \\
\hline SA025 & $\mathrm{R}$ & - & - & - & $\mathrm{R}$ & - & - & - & - & - & - & 2 \\
\hline SA026 & $\mathrm{R}$ & $\mathrm{R}$ & - & $\mathrm{R}$ & - & - & - & - & - & $\mathrm{R}$ & - & 3 \\
\hline SA027 & - & - & - & - & - & - & - & - & - & - & - & - \\
\hline SA028 & $\mathrm{R}$ & $\mathrm{R}$ & - & $\mathrm{R}$ & - & - & - & - & - & $\mathrm{R}$ & - & 3 \\
\hline SA029 & - & - & - & - & - & - & - & - & - & - & - & - \\
\hline SA030 & $\mathrm{R}$ & $\mathrm{R}$ & - & - & $\mathrm{R}$ & - & - & - & - & $\mathrm{R}$ & - & 3 \\
\hline SA031 & $\mathrm{R}$ & $\mathrm{R}$ & - & $\mathrm{R}$ & - & - & - & - & - & $\mathrm{R}$ & - & 3 \\
\hline SA032 & $\mathrm{R}$ & $\mathrm{R}$ & - & $\mathrm{R}$ & - & - & - & - & - & $\mathrm{R}$ & - & 3 \\
\hline SA033 & $\mathrm{R}$ & $\mathrm{R}$ & - & $\mathrm{R}$ & - & - & - & - & - & $\mathrm{R}$ & - & 3 \\
\hline SA034 & $\mathrm{R}$ & $\mathrm{R}$ & - & - & $\mathrm{R}$ & - & - & - & - & - & - & 2 \\
\hline SA035 & $\mathrm{R}$ & $\mathrm{R}$ & - & $\mathrm{R}$ & - & - & - & - & - & $\mathrm{R}$ & - & 3 \\
\hline SA036 & $\mathrm{R}$ & $\mathrm{R}$ & - & $\mathrm{R}$ & $\mathrm{R}$ & - & - & - & - & $\mathrm{R}$ & - & 3 \\
\hline SA037 & $\mathrm{R}$ & $\mathrm{R}$ & - & - & $\mathrm{R}$ & - & - & - & - & $\mathrm{R}$ & - & 3 \\
\hline SA038 & $\mathrm{R}$ & $\mathrm{R}$ & - & $\mathrm{R}$ & - & - & - & - & - & $\mathrm{R}$ & - & 3 \\
\hline $\begin{array}{l}\text { Total R/N } \\
(\%)\end{array}$ & $\begin{array}{l}36 / 38 \\
(94.7)\end{array}$ & $\begin{array}{l}36 / 38 \\
(92.1)\end{array}$ & $\begin{array}{c}0 / 38 \\
(0)\end{array}$ & $\begin{array}{l}13 / 38 \\
(34.2)\end{array}$ & $\begin{array}{l}14 / 38 \\
(36.8)\end{array}$ & $\begin{array}{c}0 / 38 \\
(0)\end{array}$ & $\begin{array}{c}0 / 38 \\
(0)\end{array}$ & $\begin{array}{c}0 / 38 \\
(0)\end{array}$ & $\begin{array}{c}4 / 38 \\
(10.5)\end{array}$ & $\begin{array}{l}34 / 38 \\
(89.5)\end{array}$ & $\begin{array}{c}0 / 38 \\
(0)\end{array}$ & \\
\hline
\end{tabular}

R, Resistant; (-), No resistant; AML, Amoxycillin; P, Penicillin G; CRO, Ceftriaxone; CAZ, Ceftazidime; KF, Cephalothin; CTX, Cefotaxime; CN, Gentamicin; S, Streptomycin; SF, Sulphafurazole; CIP, Ciprofloxacin; NA, Nalidixic Acid; R, Resistant S. aureus; N, Number of S. aureus. 
Table 4. Blast results against NCBI 16S ribosomal RNA sequences (Bacteria only) Database, excluding uncultured Bacteria bacterium (taxid: 77133)

\begin{tabular}{llcc}
\hline Isolates & \multicolumn{1}{c}{ Species/Subspecies } & Base pair & Per Ident \\
\hline SA14 & Staphylococcus aureus strain 16S ribosomal RNA & $1489 \mathrm{bp}$ & $99.87 \%$ \\
SA15 & Staphylococcus aureus strain ATCC 12600 16S ribosomal RNA, complete sequence & $1490 \mathrm{bp}$ & 98.46 \\
SA16 & Staphylococcus aureus strain S33 R 16S ribosomal RNA, complete sequence & $1552 \mathrm{bp}$ & $99.87 \%$ \\
SA17 & Staphylococcus aureus strain ATCC 12600 16S ribosomal RNA, complete sequence & $1490 \mathrm{bp}$ & $99.80 \%$ \\
SA18 & Staphylococcus aureus strain NBRC 100910 16S ribosomal RNA gene, partial sequence & $1477 \mathrm{bp}$ & $100 \%$ \\
SA19 & Staphylococcus aureus strain S33 R 16S ribosomal RNA, complete sequence & $1552 \mathrm{bp}$ & $99.87 \%$ \\
SA20 & Staphylococcus aureus strain ATCC 12600 16S ribosomal RNA, partial sequence & $1476 \mathrm{bp}$ & $100 \%$ \\
SA21 & Staphylococcus aureus subsp. anaerobius strain MVF-7 16S ribosomal RNA, partial sequence & $1476 \mathrm{bp}$ & $99.93 \%$ \\
SA22 & Staphylococcus aureus strain S33 R 16S ribosomal RNA, complete sequence & $1552 \mathrm{bp}$ & $99.59 \%$ \\
SA23 & Staphylococcus aureus strain 16S ribosomal RNA & $1492 \mathrm{bp}$ & $99.93 \%$ \\
\hline
\end{tabular}

A $8 \quad$ Adherence of MDRSA at $25^{\circ} \mathrm{C}$ for $24,48,72 \mathrm{~h}$ incubation time
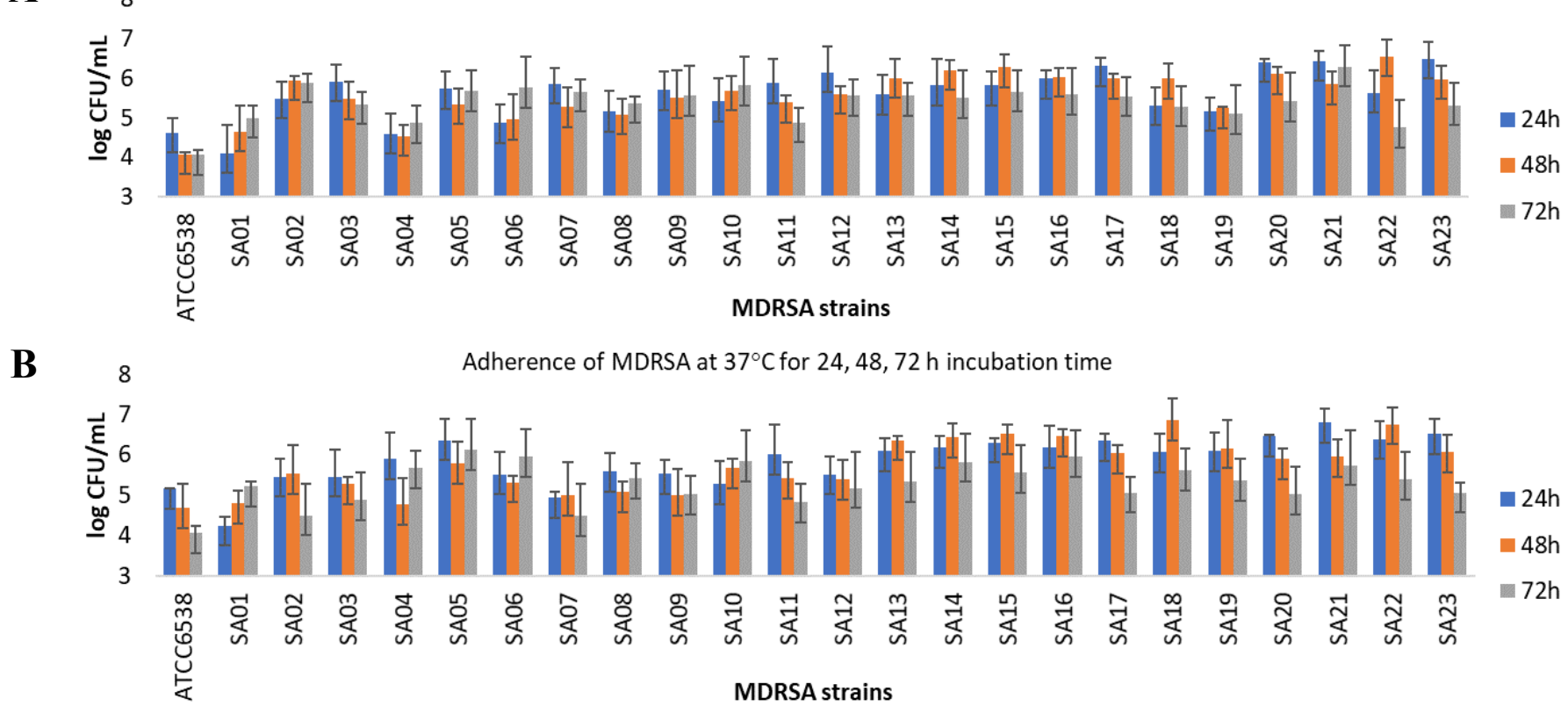

Figure 3. The adherence of MDRSA strains $\left(n=23\right.$, SA01-SA23) on stainless steel surfaces at $25^{\circ} \mathrm{C}(\mathrm{A})$ and $37^{\circ} \mathrm{C}(\mathrm{B})$ incubation temperature in 24, 48 and $72 \mathrm{hrs}$ incubation time. The adherence ability of each stains was expressed in terms of viable cell growth $(\log \mathrm{CFU} / \mathrm{mL})$ in BHI.

Table 5. The pattern of trends obtained in adherence of MDRSA strains at $25^{\circ} \mathrm{C}$ and $37^{\circ} \mathrm{C}$.

\begin{tabular}{|c|c|c|c|c|}
\hline \multirow{3}{*}{ Trend } & \multirow{3}{*}{ Pattern of the trend } & \multirow{3}{*}{ Description } & \multirow{2}{*}{\multicolumn{2}{|c|}{$\frac{\text { Percentage of MDRSA }(\mathrm{n}=23)}{\text { Temperature }}$}} \\
\hline & & & & \\
\hline & & & $25^{\circ} \mathrm{C}$ & $37^{\circ} \mathrm{C}$ \\
\hline I & 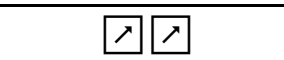 & Linear increasing & $13.0 \%(3)$ & $8.7 \%(2)$ \\
\hline II & $\Delta \square$ & Linear decreasing & $26.1 \%(6)$ & $30.4 \%(7)$ \\
\hline III & $\triangle \square$ & Increase and decrease & $34.8 \%(8)$ & $39.1 \%(9)$ \\
\hline IV & $\nabla$ & Decrease and increase & $26.1 \%(6)$ & $21.7 \%(5)$ \\
\hline
\end{tabular}

under the static conditions (Meira et al., 2012; Souza et al., 2014). This might be correlated with the irreversible adhesion stage as mentioned in the review of Garrett et al. (2008), a reversibly of the adsorbed cells number keep on restrained and become irreversibly adsorbed. This behavior could be correlated to the cell division process in forming the biofilm (Stoodley et al., 2002; Meira et al., 2012).

According to Onyango et al. (2012), the change in temperature is an important factor affecting bacterial growth and determines whether or not the bacteria can stay viable in potentially harsh and prolonged transmission situations between hosts. Moreover, temperature is the most common barrier used to control the growth of microorganisms. When $S$. aureus incubated in synthetic media, Malheiros et al. (2010) and Rode et al. (2007) noted the adherence on stainless steel surfaces and the highest adherence ability at $25^{\circ} \mathrm{C}-30^{\circ}$ $\mathrm{C}$, respectively. They noted an increase in the count of adhered cells at $37^{\circ} \mathrm{C}$ (the optimum temperature for bacterial growth) in comparison to lower incubation 
temperatures $\left(25^{\circ} \mathrm{C}\right)$. The bacterial adhesion process will only occur at maximum growth when the bacteria are kept next to their optimum temperature.

\subsection{Morphology observation of MDRSA colonies as an affected by temperature and time.}

The MDRSA colonies showed different sizes and colours at $25^{\circ} \mathrm{C}$ and $37^{\circ} \mathrm{C}$ (Figure 4). The colony growth after $24-48 \mathrm{hrs}$ at $25^{\circ} \mathrm{C}$ was smaller in size and more faded compared to $37^{\circ} \mathrm{C}$. These differences in colony presence show that a lower temperature affected the growth of all MDRSA strains. Onyango et al. (2012) stated the changes in temperature are an important factor affecting bacterial growth particularly for pathogens like staphylococci, as the temperature is the most common barrier used to control the growth of bacteria.

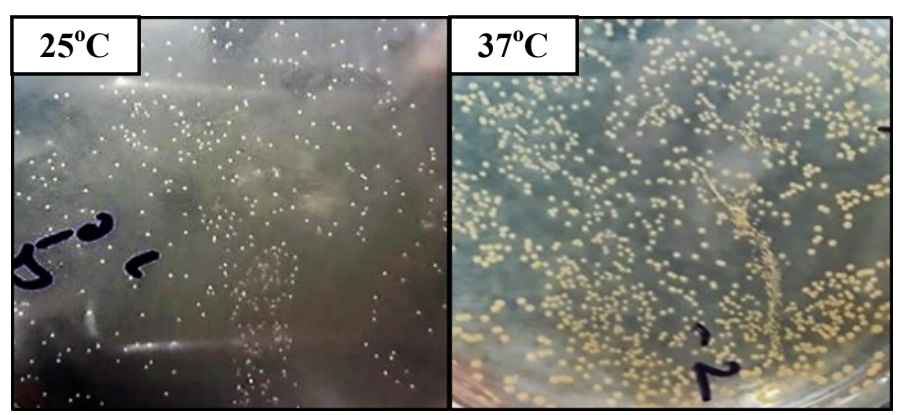

Figure 4. The colony formation of $S$. aureus on PCA at $25^{\circ} \mathrm{C}$ and $37^{\circ} \mathrm{C}$.

Abdollah et al. (2014) and Schulte (2015) believed that possibly the most significant effect of temperature on microbial growth is on the shape of its enzymes, which are commonly required for metabolism. The enzymes will have a good shape only within a relatively slight range of temperatures. It may fit a lower metabolic activity when it is at a lower temperature since the cell itself grows in a stressed condition (Somero, 2004; Angilletta, 2009). Although this work aimed to investigate the adherence of viable MDRSA cell growth at $25^{\circ} \mathrm{C}$ and $37^{\circ} \mathrm{C}$ on stainless steel surfaces, the result also shows a difference in the colony formation between these two temperatures. The result presents the consequence of MDRSA when exposed to a low temperature $\left(25^{\circ} \mathrm{C}\right)$ for elongated periods, and how this factor influences their subsequent growth and colony morphology.

\subsection{Presence of small colony variants (SCV)}

The exposure of all twenty-three MDRSA strains to prolonged low temperature resulted in the formation of presumptive small colony variant (SCV) phenotypes. Onyango et al. (2008) stated that these variants are characterised by mostly non-haemolytic and nonpigmented tiny colonies, about $1 / 10$ the size of their wild -type (WT) counterparts. These represent subpopulations of bacteria that exhibit atypical growth features from those seen in their WT counterparts (Looney, 2000; Onyango et al., 2008). Staphylococci must have the ability to survive on inanimate objects through the transition processes from one host to another (Prescott $e t$ al., 2002; Tuchscherr et al., 2010).

Prescott et al. (2002) mentioned that a temperature of $25^{\circ} \mathrm{C}$ is often applied during food processing. Although staphylococci can grow over a wide temperature range $\left(6.5-46^{\circ} \mathrm{C}\right)$, their optimal range is 30 $-37^{\circ} \mathrm{C}$. The ability of staphylococci to rapidly adapt to low and high temperatures is particularly crucial for their pathogenic strains (Singh et al., 2008). Onyango et al. (2012) discovered the rates of change in SCV numbers in terms of viable bacterial populations over a week of exposure time and observed associated changes in cellwall morphology and composition with the naked eye under a light plate counter. Based on colony characterization, the colony was physically assessed and categorised into two groups based on size and pigmentation. The colonies were characterised as SCVs if they presented pinpoint colonies $(<1 \mathrm{~mm}$ in diameter) with decreased haemolytic activity and pigmentation colonies 24-48 hrs post-incubation, as described in previous studies (Kipp et al., 2004; Seifert et al., 2005; Von Eiff et al., 2006).

\section{Conclusion}

From this study, the isolation, identification and multidrug resistant properties of $S$. aureus from food contact surfaces were determined. The adherence of multidrug-resistant $S$. aureus (MDRSA) on stainless steel surfaces at temperatures of $25^{\circ} \mathrm{C}$ and $37^{\circ} \mathrm{C}$ was assessed in $24 \mathrm{hrs}, 48 \mathrm{hrs}$ and $72 \mathrm{hrs}$ of incubation time. The result showed the strains had a better capacity to adhere on stainless steel surfaces at $37^{\circ} \mathrm{C}$ compared to $25^{\circ} \mathrm{C}$. Therefore, MDRSA shows strong adherence ability at its optimum growth temperature.

\section{Conflict of interest}

The authors declare no conflicts of interest.

\section{Acknowledgments}

The authors would like to thank Ministry of Higher Education Malaysia for financial support throughout this research with the Fundamental Research Grant Scheme (FRGS/1/2015/ST03/UPM/02/4).

\section{References}

Abdollah J., Saeid K., Majid A., Mohammad A. and Mohammad H. (2014). Modeling the growth 
of Staphylococcus aureus as affected by black zira (Bunium persicum) essential oil, temperature, $\mathrm{pH}$ and inoculum levels. Veterinary Research Forum, 5 (2), 107-114.

Angilletta, M.J. (2009). Thermal adaptation: A theoretical and empirical synthesis. New York: Oxford University Press. https:// doi.org/10.1093/acprof:oso/9780198570875.001.1

Arellano, C.K. (2010). The calcification of Staphylococcus aureus bacteria: a potential defense mechanism against infections. San Diego, USA: University Collegy San Diego, PhD Dissertation.

Cabeça, T.K., Pizzolitto, A.C. and Pizzolitto, E.L. (2012). Activity of disinfectants against foodborne pathogens in suspension and adhered to stainless steel surfaces. Brazilian Journal of Microbiology, 43 (3), 1112-1119. https://doi.org/10.1590/S151783822012000300038

Ciccio P.D., Vergara A., Festino A., Paludi D., Zanardi E., Ghidini S. and Ianieri A. (2015). Biofilm formation by Staphylococcus aureus on food contact surfaces: Relationship with temperature and cell surface hydrophobicity. Food Control, 50, 930-936. https://doi.org/10.1016/j.foodcont.2014.10.048

Clinical and Laboratory Standards Institute (CLSI), (2015). M100-S25 Performance Standards for Antimicrobial. Wayne, Philadelphia, USA: CLSI.

DeVita, M.D., Wadhera, R.K., Theis, M.L. and Ingham, S.C. (2007). Assessing the potential of Streptococcus pyogenes and Staphylococcus aureus transfer to foods and customers via a survey of hands, handcontact surfaces and food-contact surfaces at foodservice facilities. Journal of Foodservice, 18(2), 76-79. 4506.2007.00049.x

Garrett, T.R., Bhakoo, M. and Zhang, Z. (2008). Bacterial adhesion and biofilms on surfaces. Progress in Natural Science, 18(9), 10491056. https://doi.org/10.1016/j.pnsc.2008.04.001

Herrera, F.C., Santos, J.A., Otero, A. and García-López, M. L. (2006). Occurrence of foodborne pathogenic bacteria in retail prepackaged portions of marine fish in Spain. Journal of Applied Microbiology, 100(3), $527-536$. https://doi.org/10.1111/j.13652672.2005.02848.x

Hogberg, L.D., Heddini, A. and Cars, O. (2010). The global need for effective antibiotics: challenges and recent advances. Trends in Pharmacological Science 31(11), 509-515. https://doi.org/10.1016/ j.tips.2010.08.002

Ista L.K., Mendez S. and Gabriel P.L. (2010). Attachment and detachment of bacteria on surfaces with tunable and switchable wettability. Biofouling, 26(1),

111-118. https:// doi.org/10.1080/08927010903383455

Jeronimo, H.M., Queiroga, R.D., Costa, A.C., Barbosa, I.D., Conceição, M.L. and Souza, E.L. (2012). Adhesion and biofilm formation by Staphylococcus aureus from food processing plants as affected by growth medium, surface type and incubation temperature. Brazilian Journal of Pharmaceutical Sciences, 48(4), 737-745. https://doi.org/10.1590/ S1984-82502012000400018

Kipp, F., Becker, K., Peters, G. and Von Eiff, C. (2004). Evaluation of different methods to detect methicillin resistance in small-colony variants of Staphylococcus aureus. Journal of Clinical Microbiology, 42, 1277-1279. https:// doi.org/10.1128/JCM.42.3.1277-1279.2004

Kroning, I.S., Iglesias, M.A., Sehn, C.P., Gandra, T.K.V., Mata, M.M. and Silva, W.P.D. (2016). Staphylococcus aureus isolated from handmade sweets: Biofilm formation, enterotoxigenicity and antimicrobial resistance. Food Microbiology, 58, 105 -111. https://doi.org/10.1016/j.fm.2016.04.001

Looney, W.J. (2000). Small-colony variants of Staphylococcus aureus. British Journal of Biomedical Science, 57(4), 317-22.

Lucia, M., Rahayu, S., Haerah, D. and Wahyuni, D. (2017). Detection of Staphylococcus aureus and Streptococcus agalactiae: Subclinical Mastitis Causes in Dairy Cow and Dairy Buffalo (Bubalus Bubalis). America Journal of Biomedical Research, 5, 8-13. https://doi.org/10.12691/ajbr-5-1-2

Magiorakos, A.P., Srinivasan, A., Carey, R.B., Carmeli, Y., Falagas, M.E., Giske, C.G., Harbarth, S., Hindler, J.F., Kahlmeter, G., Olsson-Liljequist, B., Paterson, D.L., Rice L.B., Stelling, J., Stuelens, M.J., Vatopoulos, A., Weber, J.T. and Monnet, D.L. (2012). Multidrug-resistant, extensively drugresistant and pandrug-resistant bacteria: an international expert proposal for interim standard definitions for acquired resistance. Clinical microbiology and Infection, 18(3), 268-281. https:// doi.org/10.1111/j.1469-0691.2011.03570.x

Malheiros, P.D.S., Passos, C.T.D., Casarin, L.S., Serraglio, L. and Tondo, E.C. (2010). Evaluation of growth and transfer of Staphylococcus aureus from poultry meat to surfaces of stainless steel and polyethylene and their disinfection. Food Control, 21(3), 298-301. https://doi.org/10.1016/ j.foodcont.2009.06.008

Marques, S.C., Rezende, J.D., Alves, L.A., Silva, B.C., Alves, E., Abreu, L.R. and Piccoli, R.H. (2007). Formation of biofilms by Staphylococcus aureus on 
stainless steel and glass surfaces and its resistance to some selected chemical sanitizers. Brazilian Journal of Microbiology, 38(3), 538-543. https:// doi.org/10.1590/S1517-83822007000300029

Meira Q.G., Barbosa I.D., Athayde A.J., Siqueira-Júnior J.P. and Souza E.L. (2012). Influence of temperature and surface kind on biofilm formation by Staphylococcus aureus from food-contact surfaces and sensitivity to sanitizers. Food Control, 25(2), 469-475.

j.foodcont.2011.11.030

Noor-Azira, A.M., Mohammad-Faid, A.R., Shuhaimi, M., Syafinaz, A.N., Hamat, R.A. and Malina, O. (2012). Staphylococcus aureus in Food and Nares of Food Handlers in Kuala Pilah, Malaysia. Pertanika Journal of Tropical Agricultural Science, 35(4), 853862

Onyango, L.A., Dunstan, R.H. and Roberts, T.K. (2008). Small colony variants of staphylococci: Pathogenesis and evolutionary significance in causing and sustaining problematic human infections. Journal of Nutrition and Environmental Medicine, 17(1), 5675. https://doi.org/10.1080/13590840801887272

Onyango, L.A., Dunstan, R.H., Gottfries, J., Von Eiff, C. and Roberts, T.K. (2012). Effect of low temperature on growth and ultra-structure of Staphylococcus spp. PLoS One, 7(1), e29031. https:// doi.org/10.1371/journal.pone.0029031

Prescott, L.M., Harley, J.P. and Klein, D.A. (2002) Microbial growth: The influence of environmental factors on growth. Microbiology. 5th ed. New York, USA: McGraw-Hill.

Public Health England. (2014). Catalase Test. UK Standards for Microbiology Investigations. United Kingdom: Public Health England.

Rode, T.M., Langsrud, S., Holck, A. and Møretrø, T. (2007). Different patterns of biofilm formation in Staphylococcus aureus under food-related stress conditions. International Journal of Food Microbiology, 116(3), 372-383. https:// doi.org/10.1016/j.ijfoodmicro.2007.02.017

Baharudin, S. and Mohd Ishak, M.F. (2017). Staphylococcus aureus food poisoning outbreak among primary religious school students in Bangi 2017. The Medical Journal of Malaysia, 72 (Supplement 1), A166.

Sasidharan, S., Prema, B. and Yoga, L.L. (2011). Antimicrobial drug resistance of Staphylococcus aureus in dairy products. Asian Pacific Journal of Tropical Biomedicine, 1(2), 130-132. https:// doi.org/10.1016/S2221-1691(11)60010-5

Schulte, P.M. (2015). The effects of temperature on aerobic metabolism: towards a mechanistic understanding of the responses of ectotherms to a changing environment. Journal of Experimental Biology, 218(12), 1856-1866. https:// doi.org/10.1242/jeb.118851

Seifert, H., Oltmanns, D., Becker, K., Wisplinghoff, H. and von Eiff, C. (2005) Staphylococcus lugdunensis pacemaker-related infection. Emerging Infectious Disease, 11, 1283-1286.

Singh, V.K., Hattangady, D.S., Giotis, E.S., Singh, A.K., Chamberlain, N.R., Stuart, M.K. and Wilkinson, B.J. (2008). Insertional Inactivation of Branched-Chain alpha-Keto Acid Dehydrogenase in Staphylococcus aureus Leads to Decreased Branched-Chain Membrane Fatty Acid Content and Increased Susceptibility to Certain Stresses. Applied and Environmental Microbiology, 74, 5882-5890. https://doi.org/10.1128/AEM.00882-08

Sit, P.S., Teh, C.S., Idris, N., Sam, I., Omar, S.F., Sulaiman, H. and Ponnampalavanar, S. (2017). Prevalence of methicillin-resistant Staphylococcus aureus (MRSA) infection and the molecular characteristics of MRSA bacteraemia over a twoyear period in a tertiary teaching hospital in Malaysia. BMC Infectious Diseases, 17, 274. https:// doi.org/10.1186/s12879-017-2384-y

Somero, G.N. (2004). Adaptation of enzymes to temperature: searching for basic "strategies". Comparative Biochemistry and Physiology Part B. Biochemistry and Molecular Biology, 139(3), 321333. https://doi.org/10.1016/j.cbpc.2004.05.003

Souza, E.L., Meira, Q.G., de Medeiros Barbosa, I., Athayde, A.J., da Conceição, M.L. and de Siqueira Júnior, J.P. (2014). Biofilm formation by Staphylococcus aureus from food contact surfaces in a meat-based broth and sensitivity to sanitizers. Brazilian Journal of Microbiology, 45(1), $67-75$. https://doi.org/10.1590/S151783822014000100010

Stoodley, P., Sauer, K., Davies, D.G. and Costerton, J.W. (2002). Biofilms as complex differentiated communities. Annual Reviews in Microbiology, 56 (1), 187-209. https://doi.org/10.1146/ annurev.micro.56.012302.160705

Tan, S.L., Lee, H.Y. and Mahyudin, N.A. (2014). Antimicrobial resistance of Escherichia coli and Staphylococcus aureus isolated from food handler's hands. Food Control, 44, 203-207. https:// doi.org/10.1016/j.foodcont.2014.04.008

Thirunavukkarasu, S. and Rathish, K.C. (2014). Evaluation of Direct Tube Coagulase Test in Diagnosing Staphylococcal Bacteremia. Journal of Clinical and Diagnostic Research, 8(5), DC19- 
DC21.

Tuchscherr, L., Löffler, B., Buzzola, F.R. and Sordelli, D.O. (2010). Staphylococcus aureus adaptation to the host and persistence: role of loss of capsular polysaccharide expression. Future Microbiology, 5 (12), 1823-1832. https://doi.org/10.2217/fmb.10.147

Von Eiff, C., Peters, G. and Becker, K. (2006). The small colony variant (SCV) concept the role of staphylococcal SCVs in persistent infections. Injury, 37, S26-S33. https://doi.org/10.1016/ j.injury.2006.04.006 